\title{
HISTÓRIA, MEMÓRIA E MITO NO \\ ROMANCEIRO DA INCONFIDÊNCIA
}

\author{
Sílvia Carneiro Lobato Paraense \\ GRPESQ/ CNPq Discurso, História, Gênero e Identidade \\ Gabinete de Leitura
}

Este é o esboço de uma tentativa de abordagem do texto do Romanceiro da Inconfidência ${ }^{1}$ a partir das relações que 0 poema estabelece com suas fontes históricas e também com a memória e a ideologia. Pressuposto um primeiro momento, no qual o texto literário é submetido à análise intrínseca ${ }^{2}$, busca-se nessa fase lançar mão de conceitos teóricos bem como de documentos pertencentes à ordem da realidade empírica, elementos que participaram da construção mesma do texto, conforme depoimento da própria autora ${ }^{3}$.

O objetivo foi verificar a representação da identidade nacional no Romanceiro, para isso recorrendo ao mito de fundação da nacionalidade brasileira segundo o modelo proposto por Marilena Chauí em Brasil - mito fundador e sociedade autoritária ${ }^{4}$.

Com efeito, na reconstrução dos acontecimentos de que trata o poema, alternam-se vozes oficiais (retomadas dos textos que compõem o relato histórico), a memória da comunidade, murmurada na tradição oral, guardadora dos silenciamentos impostos pelo poder aos fatos da rebelião. No jogo de memória e esquecimento constroem-se as diferentes versões da história, marcadas sucessivamente pela ideologia de cada época. Assim também se alternam, no Romanceiro, os diversos planos (oficiais, escritos; orais, comunitários) constituídos por discursos informados segundo diferentes pontos de vista e sistemas de valores.

Ao apresentar Tiradentes, a personagem histórica sobre a qual recai o peso da sentença real, como mártir sacrificado pelos ideais de justiça e liberdade, o Poema retoma o mito fundador da nacionalidade brasileira. Isso porque o sacrifício transforma a personagem em herói mítico - o herói redentor cujo martírio possibilita a restauração da harmonia no mundo degradado. Com

fragmentum. Santa Maria: UFSM, №1, 2001. 
isso, é recuperado o estado de pureza presente no mito da perfeição do Paraíso.

\section{IDENTIDADE}

Observar a questão da identidade significa, antes de tudo, rastrear a diferença. Sem o diferente, sem o outro, é impossível a existência do idêntico, do mesmo. Portanto, tratar de identidade significa, antes de mais nada, buscar o que distingue, o que singulariza. As questões relativas a identidade e diferença são sempre questões problemáticas, uma vez que ambas são construções. Construções imaginárias.

Em que sentido se pode afirmar que se investiga a questão da identidade no texto literário? Além disso, com que objetivo se pretende essa investigação? Tais perguntas são necessárias, uma vez que podem levar a enfoques bastante distintos, dependendo do que se pretende observar.

São possíveis objetos de indagação, por exemplo, a identidade relativa

a) ao gênero (gerando textos críticos que tratam de buscar a expressão do "feminino");

b) ao grupo étnico;

c) à posição frente ao poder (colonialista, dominante, desenvolvido);

c) à singularidade do indivíduo enquanto subjetividade.

A constatação da diferença da literatura brasileira em relação aos demais sistemas literários, especialmente à literatura portuguesa, já vem formulada por Machado de Assis, quando assevera a possibilidade de se reconhecer o escritor brasileiro, mais que pelo material escolhido como objeto da obra - "a vida brasileira e a natureza americana" -, pelo "sentimento íntimo, que o torne homem do seu tempo e do seu país, ainda quando trate de assuntos remotos no tempo e no espaço" ${ }^{1}$. Dessa perspectiva, a questão identitária afigura-se como um desenho feito a partir de linhas mestras passíveis de serem identificadas em sua singularidade.

O que são e quais são essas linhas? Como identificá-las, reconhecê-las? 
Se a identidade é uma construção imaginária, questões concernentes a ela passam, necessariamente, por campos de sentidos e valores capazes de unificar uma concepção da realidade compartilhada por um grupo. Isto equivale a dizer que a identidade é um processo que vai-se construindo no âmbito do simbólico, em relação com a história, a memória, a ideologia.

\subsection{Identidade: nacionalidade e mito fundador}

\section{Em Brasil - mito fundador e sociedade autoritária,} Marilena Chauí utiliza categorias propostas por Eric Hobsbawm ${ }^{6}$ para dar conta do desenvolvimento do liberalismo no ocidente. Hobsbawm localiza em 1830 o surgimento do conceito de nação com o sentido que the é hoje atribuído, qual seja, o sentido político de Estado-nação. Anteriormente, os termos empregados em política para designar conceitos próximos eram "povo" e "pátria". Para o historiador inglês, o conceito se desenvolve segundo três etapas sucessivas:

- a primeira, de 1830 a 1880, em que prepondera o "princípio de nacionalidade:", o qual vincula a existência da nação à unidade política e a uma extensão territorial "viável";

- o segundo período, de 1880 a 1918, é dominado pela "idéia nacional", que vincula à nação a unidade lingüística, cultural e de raça;

- a terceira fase, de 1918 aos anos 1950-60, é a fase da "questão nacional", que enfatiza a consciência nacional, definida por um conjunto de lealdades políticas. ${ }^{7}$

Para Chauí, "o processo histórico de invenção da nação nos auxilia a compreender um fenômeno significativo no Brasil, qual seja, a passagem da idéia de 'caráter nacional' [que Hobsbawm identifica com o segundo momento do processo de desenvolvimento do conceito de nação] para a de 'identidade nacional' [relativa ao terceiro momento]. O primeiro corresponde, grosso modo, aos períodos de vigência do 'princípio de nacionalidade' (1830-1880) e da 'idéia nacional' (1880-1918), enquanto a segunda aparece no período da 'questão nacional' (1918-1960)." 
A partir dessa perspectiva, Chauí trabalha o mito fundador da nacionalidade brasileira, identificando-o à ideologia do verdeamarelismo. Segundo essa ideologia, o Brasil é o país de todas as possibilidades, onde uma natureza exuberante e benfazeja é berço esplêndido de um homem generoso e pacífico.

Para analisar a especificidade da criação imaginária da identidade nacional, a autora parte do esclarecimento de termos. Tratar de mito fundador exige, inicialmente, que seja estabelecida a distinção entre formação (um processo histórico) e fundação (momento do passado imaginário, percebido como instante originário que se mantém vivo, estabelecendo a estrutura de sustentação do curso temporal e conferindo-Ihe sentido). O vocábulo mito, então, é empregado em dois sentidos. O primeiro, etimológico ( ' grego mythos), segundo o qual o mito é uma narração pública de feitos lendários da comunidade. Mito também se reveste de seu sentido antropológico, ou seja, equivale a uma narrativa que apresenta a solução imaginária para tensões, conflitos e contradições que não são possíveis de se resolver no nível da realidade.

Chauí ainda esclarece que o mito apresenta-se como fundador porque, como toda fundatio, impõe um vínculo interno com o passado como origem, isto é, com um passado que não cessa nunca, que se conserva perenemente presente e, por isso mesmo, não permite o trabalho da diferença temporal e da compreensão do presente enquanto tal. Desse modo, "um mito fundador é aquele que não cessa de encontrar novos meios para exprimir-se, novas linguagens, novos valores e idéias, de tal modo que, quanto mais parece ser outra coisa, tanto mais é a repetição de si mesmo." " Marca peculiar da fundação é a maneira como é concebida: parece emanar da sociedade (ou nação) e, simultaneamente, engendrar essa sociedade (ou nação) da qual emana.

Da perspectiva de Chauí, o mito fundador da nacionalidade brasileira é uma construção imaginária em processo no decurso do tempo, que lança seus fundamentos desde a identificação do país recém-descoberto com o mundo paradisíaco proposto como possibilidade milenarista de mitos oriundos da tradição judaicocristã, e que têm seu fundamento na Bíblia. 
A partir do relato do Gênesis e das grandes profecias, principalmente as de Isaías, além dos textos de autores latinos como Ovídio e Virgílio, a literatura cristã medieval desenvolve o tema do paraíso terrestre, cujos rios manam leite e mel, cujos leitos são de ouro, prata e pedras preciosas, cujos habitantes são belos e inocentes como no dia da criação. Esse tema recebe sua figuração herética nas doutrinas milenaristas de Joaquim de Fiori, além de estar presente nas lendas fenícias que localizam uma terra paradisíaca a oeste, além das Colunas de Hércules, que chamaram Braaz e os monges irlandeses designaram Hy Brazil. Essas terras estão registradas nos mapas medievais entre 1325 e 1482, a oeste da Irlanda e ao sul dos Açores, a Insulla de Brazil ou Isola de Brazil, a terra bem-aventurada. ${ }^{10}$

Chauí toma como exemplo da influência dessa concepção do Novo Mundo a Carta de Pero Vaz de Caminha, e aí reconhece "os três signos paradisíacos decifráveis por todo leitor dos séculos XVI e XVII":

1. a referência à abundância e à boa qualidade das águas - o que significa que a terra achada é cortada pelos rios de que fala o Gênesis;

2. a temperatura amena - sugerindo tacitamente a eterna primavera; e

3. as qualidades da gente, descrita como bela e altiva, simples e inocente - afirmando tacitamente sua identificação com as gentes a que se refere o profeta Isaías. ${ }^{11}$

Cartas e diários de bordo descrevem o mundo recémdescoberto como novo e outro. No entanto, tais termos recebem um sentido diverso do esperado. Mundo novo não significa mundo desconhecido; nem esta mundo é outro por ser inteiramente diferente da Europa. É novo porque é o retorno à perfeição da origem, à "novação do mundo", oposto à velhice ou à decadência do velho mundo. E outro por ser o mundo da origem, isto é, anterior à queda do homem. "Essa 'visão do paraíso', o topos do Oriente como jardim do Éden, essa Insulla de Brazil ou Isola de Brazil, são constitutivos da produção da imagem mítica fundadora do Brasil"12.

A ideologia do verde-amarelismo, cujo nascimento foi traçado por Marilena Chauí desde o "achamento" da terra nova, vai 
sofrendo transformações através do tempo. No período inaugurado pela República faz-se necessário um novo perfil de nação. A esse perfil adequa-se um "herói fundador". Tal herói será encontrado na figura histórica de Tiradentes, silenciada pelo regime monárquico, transformada em "herói redentor", figura mítica recorrente como elemento regenerador, restaurador das possibilidades de vida em um universo degradado. A partir do mito do redentor, a realidade pode ser reconstruída em sua pureza original. É esse herói mitificado que ocupará o centro do poema ceciliano publicado em 1953.

\section{MEMÓRIA / ESQUECIMENTO}

\subsection{Memória social - memória coletiva}

Acontecimentos geram discursos que circulam entre os membros de um grupo. A retomada de discursos cria uma memória. Por transitar entre os membros da comunidade, essa retomada constitui uma questão social.

Toda memória só se constrói a partir do sentido. Isso significa que, "para que haja memória, é preciso que o acontecimento ou o saber registrado saia da indiferença, que ele deixe o domínio da insignificância". ${ }^{13}$ Enquanto a lembrança circula entre os membros do grupo sob forma oral, constitui memória coletiva, memória social.

Ao tratar da memória social, Jean Davalon retoma conceitos de Maurice Halbwachs acerca da constituição da memória coletiva. Halbwachs ${ }^{14}$ refere a maneira como se constitui a memória coletiva a partir de um fundo comum, de uma dimensão intersubjetiva, vale dizer, de conhecimentos e valores compartilhados pelos membros de uma comunidade social. A memória coletiva, no entanto, apresenta uma característica de instabilidade, ou impermanência: é responsável pela conservação do passado mas, ao mesmo tempo, não é capaz de assegurar a permanência das lembranças, uma vez que o que é vivo na consciência do grupo desaparecerá com o desaparecimento de seus membros. ${ }^{15}$ 
Outro aspecto que deve ser ressaltado acerca da memória é o fato de ela não ser capaz de acumular ilimitadamente fatos, caso em que se daria o colapso provocado por um mecanismo de saturação. Para que a memória não se sature, é necessário que, periodicamente, alguns fatos sejam esquecidos. Assim, é próprio tanto da memória coletiva quanto do processo histórico o fluxo/refluxo da alternância entre memória e esquecimento. Com o transcurso do tempo, algumas coisas esquecidas retornam, e passam por um novo processo de interpretação.

\subsection{Memória e história}

Materializada em narrativa escrita, a memória social é regularizada, transformada em história. Para que haja regularização é necessário repetição ou, como afirma Pierre Achard, "a regularização se apóia necessariamente sobre o reconhecimento do que é repetido." ${ }^{16}$

Essa regularização que a história impõe sobre 0 acontecimento determina a forma como, daí em diante, serão retomados e circularão os discursos sobre esse acontecimento. Achard afirma ainda que "um texto dado trabalha através de sua circulação social, o que supõe que sua estruturação é uma questão social, e que ela se diferencia seguindo uma diferenciação das memórias e uma diferenciação das produções de sentido a partir das restrições de uma forma única." ${ }^{11}$ Por isso, a memória coletiva transformada em história de certa maneira cristaliza a visão do acontecimento, tornado monumento ao se materializar em arquivo.

No entanto, a história, versão estabelecida e consensual dos acontecimentos, não está constituída como um bloco petrificado e imóvel. Ela também se transforma a partir do deslizamento de sentidos atribuídos aos fatos, isto é, pelo impacto da ideologia. Essa pressão ideológica reativará sentidos que foram silenciados em determinado momento, transformando, ao sabor dos novos valores, a construção de um novo sentido para o acontecimento já cristalizado em um outro pano de fundo de referências.

fragmentum. Santa Maria: UFSM, №1, 2001. 


\section{HISTÓRIA}

\subsection{A Inconfidência Mineira e a história}

Durante o período colonial e o Primeiro Império, a Inconfidência Mineira é assunto silenciado da história brasileira, uma vez que os réus haviam sido condenados por crime de lesamajestade. Daí não haver referências ao movimento após a conclusão dos Autos da Devassa. A história censura, silencia a Inconfidência que, no entanto, permanece na memória coletiva. No Império, após a Independência, persiste o tabu com relação ao acontecimento, pois o Imperador era neto da rainha que assinou a sentença contra os inconfidentes.

O silenciamento oficial imposto à conjura, no entanto, carrega-se de ambigüidade: por um lado, não são feitas referências ao acontecimento. Por outro, este deve permanecer na memória como castigo exemplar a que fazem jus aqueles que se rebelam contra o trono. Assim, o mesmo processo apresenta dois sentidos, permitindo a persistência da memória, através da execração, daquilo que se quer calar. Aí se pode observar em ação a constatação de Eni Orlandi acerca do silenciamento imposto pela censura:

Pensada através da noção de silêncio [...], a própria noção de censura se alarga para compreender qualquer processo de silenciamento que limite o sujeito no percurso de sentidos. Mas mostra ao mesmo tempo a força corrosiva do silêncio que faz significar em outros lugares o que não "vinga" em um lugar determinado. O sentido não pára, ele muda de caminho. $^{18}$

É interessante observar a modificação de sentido atribuído ao nome, altamente pejorativo, que se fixou como designativo da Conjuração. Inconfidência, ação de inconfidentes: aqueles em quem não se pode depositar confiança, não confiáveis (traidores). Observa-se que os primeiros autores a se referirem ao movimento evitam denominá-lo Inconfidência, preferindo o nome Conjuração Mineira. Aos poucos, Conjuração foi sendo substituído por Inconfidência, e o termo passou, de pejorativo, a se revestir de caráter positivo. 
Nada foi escrito sobre a Conjuração no século XVIII e primeira metade do século XIX, nem na história portuguesa, nem tampouco no Brasil, afora os Autos e a sentença condenatória dos inconfidentes assinada pela Rainha D Maria I. Quem se refere ao movimento são apenas os estrangeiros. Segundo a concepção histórica tradicional, o primeiro a comentar o acontecimento é o inglês Robert Southey, autor de uma história do Brasil (1810-1819) escrita a partir de documentos colhidos por Herbert Hill, traduzida para o português por Luiz de Castro. A fonte para a referência à Inconfidência é a sentença da Rainha. O segundo é o publicista e político republicano francês Charles Ribeyrolles que, refugiado no Brasil a partir de 1858, durante sua estada no Rio de Janeiro descreve a paisagem e os costumes locais em Brasil pitoresco (1859). Ao ocupar-se do episódio da Conjuração Mineira, também tem vistas à sentença, transcrevendo-a.

Como ilustração do silenciamento imposto à Conjuração Mineira, apresenta-se a seguir a lista, por ordem cronológica, de textos que mencionam esse episódio:

1798 - George Stauton - An Authentic account of an Embassy from the King of Great Britain to the Emperor of China, reproduzido por

\section{state of the universe.}

1810 - Cavendish Pelhan - The World of the present

Herbert Hill - colhe documentos sobre a história da colônia portuguesa, inclusive a Conjuração (na versão dos juízes, porque tem acesso à sentença), aproveitados na obra considerada pioneira sobre o assunto:

1810-1819 - Robert Southey: História do Brasil.

1837 - John Armitage: História do Brasil, em que o episódio da Conjuração é citado em um único parágrafo e duas notas.

Há ainda o relato, para o Instituto Histórico e Geográfico Brasileiro, de

1839 - José de Rezende Costa Filho, inconfidente que sobreviveu ao degredo, e membro do Instituto.

1859 - Charles Ribeyrolles - Brasil pitoresco.

fragmentum. Santa Maria: UFSM, nำ1, 2001. 
O primeiro relato monográfico acerca da Inconfidência escrito por um brasileiro

1873 - Joaquim Norberto de Sousa e Silva - História da Conjuração Mineira (lida em capítulos, à medida que os finalizava, para o mesmo Instituto Histórico e Geográfico). O caráter inovador da obra prende-se ao fato de Joaquim Norberto utilizar os Autos da Devassa como fonte primária da narrativa. Além dos Autos, também utiliza dois manuscritos contendo relatos de contemporâneos:

Anônimo - Memória do êxito que teve a Conjuração de Minas e dos fatos relativos a ela acontecidos nesta cidade do Rio de Janeiro desde o dia 17 até 26 de abril de 1792, possivelmente de uma testemunha ocular da condenação dos 11 presos.

- Frei Raimundo de Pena Forte - Os últimos momentos dos inconfidentes de 1789 pelo frade que os assistiu em confissão.

\subsection{História - função da ideologia}

A partir dessa cronologia observa-se que o assunto da Inconfidência Mineira durante o período colonial, quando não é silenciado, vem mencionado de maneira sumária e exemplar. $\mathrm{O}$ julgamento dos Inconfidentes é documentado nos Autos da Devassa, aos quais se segue a sentença dos réus. Traidores do rei, a quem deveriam prestar absoluta lealdade e obediência, os conspiradores são caracterizados como indivíduos socialmente perniciosos, bem como degradados moralmente, uma vez que faltam com o dever elementar de todo súdito - de obediência e lealdade ao soberano. Como tal são referidos no processo e também na sentença.

Sirvam de exemplo do caráter pernicioso dos Inconfidentes, segundo a perspectiva do poder colonial, fragmentos da sentença citados por Ribeyrolles ${ }^{19}$ : 
em sua casa [de Francisco de Paula Freire de Andrade] se ajuntavam os mais chefes cabeças da conjuração nos infames conventículos, em que se ajustavam a forma do estabelecimento da república [...] [...] encarregando-se ultimamente fazer avisos aos conjurados do dia em que se havia executar o horroríssimo e atrocíssimo atentado, com o sinal tal dia é o batizado [...]

Mostra-se, quanto ao réu Cláudio Manoel da Costa, que suposto não assistisse nem figurasse nos conventículos que se fizeram [...] contudo soube e teve individual notícia e certeza de que estava ajustado entre os chefes da conjuração fazer-se o motim do levante, estabelecer-se uma república independente na capitania de Minas, proferindo o seu voto nesta matéria nas torpes e execrandas conferências que teve com o réu Alvarenga e o padre Carlos Correia de Toledo [...] em cujas conferências se tratava do modo de executar a sedição e levante e dos meios do estabelecimento da república, [...] constituindo-se pelas ditas infames conferências também chefe da conjuração [...], e tanto se reconheceu este réu criminoso de lesa-majestade da primeira cabeça, que horrorizado com o temor do castigo que merecia pela qualidade do delito, que [...] foi achado morto no cárcere em que estava, afogado com uma liga $[\ldots]$

Mostra-se que este réu é de tão péssima conduta e de consciência tão depravada que julgando estar descoberta a conjuração [...]

Mostra-se que os infames réus cabeças da conjuração teriam suscitado o levante na ocasião da derrama [...] se o coronel Joaquim Silvério dos Reis se esquecesse das obrigações de católico e de vassalo, e de desempenhar a honra e fidelidade de português, deixando de delatar a prática e convite que Ihe fizeram [...] para entrar na conjuração [...] persuadidos de que o dito coronel Joaquim Silvério dos Reis queria ajudar a rebelião para se ver livre da grande dívida que devia à fazenda real, sendo um dos artigos da negra conjuração perdoarem-se as dívidas a todos os devedores da real fazenda; mas prevalecendo no dito coronel Joaquim Silvério dos 
Reis a fidelidade e a lealdade que devia ter, como vassalo da dita Senhora, delatou tudo ao governador da capitania de Minas em 15 de Março de 1789 [...]; e ainda que houve a louvável denúncia do tenente-coronel Basílio de Brito Malheiro e de Inácio Correia Pamplona [...]

Portanto condenam o réu Joaquim José da Silva Xavier, por alcunha o Tiradentes, alferes que foi da tropa paga da capitania de Minas, a que com baraço e pregão seja conduzido pelas ruas públicas ao logar da forca, e nela morra morte natural para sempre, e que depois de morto lhe seja cortada a cabeça e levada à Vila Rica, aonde em o lugar mais público dela será pregada em um poste alto até que o tempo a consuma; o seu corpo será dividido em quatro quartos e pregados em postes pelo caminho de Minas, o sítio da Varginha e de Sebolas, aonde $o$ réu teve as suas infames práticas, e os mais nos sítios de maiores povoações, até que o tempo também os consuma. Declaram o réu infame, e infames seus filhos e netos, tendo-os, e seus bens aplicam para o fisco e câmara real, e a casa em que vivia em Vila Rica será arrasada e salgada, e que nunca mais no chão se edifique, e não sendo próprias, serão avaliadas e pagas ao seu dono pelos bens confiscados, e no mesmo chão se levantará um padrão pelo qual se conserve em memória a infâmia deste abominável réu. ${ }^{20}$ (grifos meus)

Após transcrever a sentença, o republicano Ribeyrolles observa: "Dessa conjuração não conhecemos mais do que a versão dos juízes. A publicidade, poderoso registro, era interdita. $O$ processo foi secreto, arbitrário, e o tribunal supremo contava, nesse caso, com as prerrogativas absolutas da coroa." ${ }^{21}$

Da perspectiva do poder, a execração; do ponto de vista dos novos ideais, o martírio por uma idéia. É ainda de Ribeyrolles o comentário:

Tiradentes foi publicamente executado [...] Como o quisera a sentença, houve sinistro aparato na marcha para o suplício, e o cadafalso estava em grande gala. 
O mártir soube morrer. a multidão emocionada não viu passar um queixume, um temor, sobre essa fronte de soldado. É que ele se sacrificava por uma idéia.

[...]

O direito humano, não o direito legal, não pode acompanhar os azares da força [...] É uno e inflexível. Dirá como os americanos da independência: todos os homens nascem iguais, todos os povos devem ser livres.

Ora, nessa medida, a essa altura [segunda metade do século XIX], Tiradentes é absolvido. Antecessor vencido, precursor malogrado, ao cair, abriu caminho. E seria fraqueza não levantar esse cadáver que Portugal arrastou pelas enxovias." ${ }^{22}$ (grifos meus)

As palavras de Ribeyrolles já demonstram de que maneira será recuperado o legado da Inconfidência pela República que se instalará algum tempo depois.

\subsection{Trânsito da história para o mito}

Em 1902, portanto já em período republicano, Sílvio Romero, na História da literatura brasileira, comenta a obra de Joaquim Norberto. Como este, também Romero é um monarquista. Seu comentário considera a oportunidade da obra, por ela haver contribuído "para reduzir as proporções assustadoras que [ia] tomando [...] o mito de Tiradentes." Afirma ainda o historiador da literatura brasileira: "Não contesto aos brasileiros o direito de fantasiar heróis e encher de semideuses o céu de sua história; se Ihes praz criar uma mitologia política, criem-na como lhes bem quadrar." ${ }^{23}$

O que Romero assinala é o prestígio adquirido pelo herói da Inconfidência entre os republicanos, muito embora o desenho do herói por Joaquim Norberto não seja nada enaltecedor. Tiradentes estabeleceu-se no imaginário da República como o mártir da pátria. Desde a segunda metade do século XIX que a imagem do Alferes já

fragmentum. Santa Maria: UFSM, №1, 2001. 
surgia como símbolo da iminente República, o que se pode constatar pela proposta do movimento republicano, em 1872, da construção de um monumento em homenagem ao Alferes, no Rio de Janeiro.

Apoiado em extensa documentação, Joaquim Norberto narra a Conjuração. Seu ponto de vista não é favorável à figura de Tiradentes. Atribui-lhe qualidades francamente negativas, que 0 descredenciariam como um dos cabeças do motim. Busca diminuir sua importância no levante, considerando-o inferior tanto no aspecto intelectual quanto em relação a seu equilíbrio psicológico, o que não o indicaria como alguém de importância na conspiração. $O$ desenho do alferes procura desqualificá-lo ao atribuir-lhe defeitos como a incontinência verbal, a loucura (exteriorizada no "olhar espantado", na rudeza selvagem de suas palavras), a irresponsabilidade:

A sua fisionomia nada tinha de simpática e antes se tornava notável pelo que fosse de repelente, devido em grande parte ao seu olhar espantado [...]. Possuía, porém, o dom da palavra e expressavase as mais das vezes com entusiasmo; mas sem elegância nem atrativo, resultado de sua educação pouco esmerada; ouvindo-o porém na rudeza de sua conversação, gostava da sua franqueza selvagem, algumas vezes por demais brusca e que quase sempre degenerava em leviandade, de sorte que uns davam o característico de herói e outros o de doido. [...] Tornava-se assim o objeto de público gracejo, provocando o riso, e não poucas vezes vaias e apupadas do vulgo. ${ }^{24}$ (grifos meus)

O poema de Cecília Meireles utiliza esses dados, atribuindo-Ihes, no entanto, valores ora positivos ora negativos, dependendo da perspectiva adotada por quem faz menção aos traços. Assim com a fala, com o olhar espantado, que mantêm o valor de imprudência e loucura. No entanto, à perda do juízo se acrescenta o valor do sonho, dos olhos abertos a uma dimensão além da realidade material:

Passou um louco, montado.

Passou um louco a falar

que isso era uma terra grande 
e que a ia libertar.

$[\ldots]$

- Por isso é que assim nos rimos,

que nos rimos sem parar, pois há gente que não leva

a cabeça no lugar. (Romance $X X X$ ou Do Riso dos Tropeiros)

Por aqui passava um homem

- e como o povo se ria! -

"Liberdade ainda que tarde"

nos prometia.

E cavalgava o machinho.

E a marcha era tão segura

Que uns diziam: "Que coragem!"

e outros: "Que loucura!"

Lá se foi por esses montes

o homem de olhos espantados,

a derramar esperanças

por todos os lados. (Romance XXXI ou De Mais Tropeiros)

Outro fator de diminuição da figura do Alferes é representado por sua religiosidade. Ele, que se considerava um líder político, tendo assumido perante os juízes a responsabilidade total pela conjuração, é apresentado como um devoto. No capítulo referente à morte do inconfidente, afirma Joaquim Norberto, referindo-se ao costume de o carrasco pedir perdão ao condenado:

Algemado, tendo entre as mãos a imagem do Cristo, marchava o padecente, sem afastar os olhos do crucifixo, à exceção de duas vezes que os pôs no céu. Escreveu uma das testemunhas oculares: "Causou admiração a sua constância, e muito mais a viva devoção que tinha aos grandes mistérios da Trindade e da Encarnação, de sorte que falando-seIhes nestes mistérios [...] suas expressões eram cheias de unção, o que fez que o seu diretor [espiritual] não Ihe dissesse nada mais senão repetir com ele o símbolo de S. Atanásio." ${ }^{25}$ (grifos meus) 
Essa relação com o divino, que visa a desmerecer o herói, transferindo seu comportamento do campo da ação para o plano transcendental deixa visível que esse não é um líder político confiável, uma vez que se identifica com a aceitação passiva do fracasso, em vez de se rebelar contra ele. Tiradentes não mereceria o lugar de líder, uma vez que não tomba lutando.

No entanto, essa mesma relação com o divino abre espaço para uma outra faceta: a da transferência da figura do herói martirizado do campo da história para o plano mítico. A possibilidade desse deslizamento de planos já fôra indicada pelo republicano Ribeyrolles em seus comentários acerca do resultado da conjura. Afirma o publicista francês, ao comparar a Conjuração Mineira à guerra pela independência dos EEUU:

Tiradentes e seus companheiros seriam mesmo culpados? Sim. No direito legal que ligava as colônias às metrópoles, eles eram culpados como Washington, como Franklin, como Jean Hancok e outros rebeldes americanos do congresso de Filadélfia. Se lorde Gage, general do exército inglês, tivesse esmagado, desde as primeiras campanhas, as milícias revoltadas da América do Norte, que seria de George Washington? Talvez morto como Tiradentes, no alto de um cadafalso. Seus bens teriam sido confiscados, seus membros dilacerados, sua casa arrasada, seus filhos e netos aviltados e execrados. Mas a guerra the foi favorável, e hoje Washington é um herói. ${ }^{26}$ (grifos meus)

O que significa que Tiradentes, não tendo sido bem sucedido como um herói político no plano histórico, estava livre do peso da história para tornar-se um herói no plano do mito. Essa transferência para o nível simbólico já é concretizada na narrativa histórica de Joaquim Norberto. Tal relação com o mundo mítico pode ser observada no fragmento a seguir, referente ao final do capítulo XI da História da Conjuração Mineira. Tiradentes acaba de se retirar do palácio do vice-rei:

Retirou-se o alferes desconsoladíssimo do palácio e em caminho encontrou-se com o seu mau gênio 24 fragmentum. Santa Maria: UFSM, № 1, 2001. 
[Joaquim Silvério dos Reis]. Como querendo patentear-se mais seu amigo [...], avisou-o o coronel Joaquim Silvério que tivesse conta em si, que se retirasse [do Rio de Janeiro] pois que o vice-rei, informado de suas práticas, andava com grande cuidado sobre ele, e mais dia menos dia seria preso. Era o beijo do Iscariota! Com a bolsa recheada do preço da traição vinha sentar-se Judas à mesa de Jesus Cristo. ${ }^{27}$ (grifos meus)

Observa-se aí a aproximação explícita entre a narrativa histórica e o relato da fundação da religião cristã. Ambos os episódios comportam o traidor, que vende seu líder aos inimigos políticos, ambos opressores da gente da terra. Joaquim Silvério é explicitamente comparado a Judas, o que implicitamente aproxima Tiradentes de Cristo.

Cecília Meireles trabalha o episódio em dois romances. O primeiro, sobre o traidor:

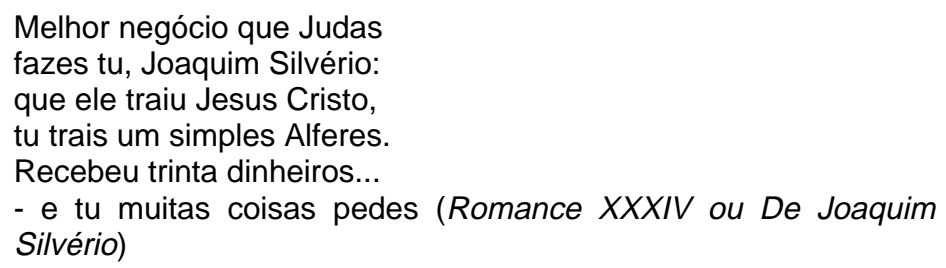

Melhor negócio que Judas fazes tu, Joaquim Silvério: que ele traiu Jesus Cristo, tu trais um simples Alferes. Recebeu trinta dinheiros...

- e tu muitas coisas pedes (Romance XXXIV ou De Joaquim Silvério)

segundo sobre as sentinelas que acompanham o alferes:

(Esses vultos que me seguem, Joaquim Silvério, quem são?

Devem ser as sentinelas

que amanhã me prenderão?

Quem as pôs sobre os meus passos?

Quem comete essa traição?

Responde, Joaquim Silvério, quem nos leva à perdição?) (Romance XXXVI ou Das Sentinelas) 


\section{Tiradentes: \\ Mais adiante, o historiador narra a execução de}

Pedindo-lhe [o carrasco] de costume o perdão da morte, pois que a justiça e não a sua vontade lhe moviam os braços, desceu Tiradentes de seu pedestal de glória para humilhar-se de mais e the dizer: "Oh! meu amigo, deixe-me beijar-Ihe as mãos e os pés!" $O$ que fez com grande admiração do próprio algoz. Ao despir-se para vestir a alva, tirou também a camisa e ungiu seus lábios com estas belas palavras: "O meu redentor morreu por mim também assim". ${ }^{28}$

Nesse ponto, Joaquim Norberto explicita as analogias. Portanto, a mitificação da figura do herói martirizado da Inconfidência Mineira é plantada pelo relato histórico. Desde então, o episódio da Inconfidência Mineira tem sido, dentre os episódios da história do Brasil, um dos que recebeu o maior número de versões literárias, segundo análise do crítico mineiro Fábio Lucas ${ }^{29}$.

Cecília Meireles serve-se também desse episódio, na das etapa final de identificação das figuras de Tiradentes e de Cristo:

Vede o mártir como fita sereno a sua desdita e o negro Capitania!

"Ó, permite que te beije os pés e as mãos... Nem te importe arrancar-me este vestido...

Pois também na cruz, despido, morreu quem salva da morte!" (Romance LVIII ou Da Grande Madrugada)

\section{ROMANCEIRO DA INCONFIDÊNCIA}

O Romanceiro, publicado em 1953, é elaborado num momento de tensão da vida brasileira, momento de transição não apenas no Brasil como também no panorama mundial, que se reorganiza segundo um novo modelo. 
Cecília Meireles afirma ter passado os dez anos que antecederam a publicação do poema envolvida em estudos que Ihe permitiram compreender e reconstituir o panorama sócio-político e cultural que cercou os acontecimentos, a geografia da região e seus caminhos.

Esse período de dez anos se estendeu desde 1943, ou seja, iniciou ainda durante a II Grande Guerra. Os dois anos finais, nos quais a poeta afirma ter-se dedicado integral e exclusivamente à composição do texto, correspondeu, no Brasil, aos últimos anos do governo Vargas, que se suicida em agosto de 1954. Observa-se, então, que o poema é pensado e gerado em um momento de transição na vida social brasileira, bem como na vida da cultura ocidental. Além disso, situa-se a sua produção na terceira fase de configuração do conceito de nação, aquele que vai de 1918 aos anos 1950-60, no qual se dá a problematização da "questão nacional", vale dizer, o conceito de Estado-nação repousa na ênfase atribuída à consciência nacional, definida por um conjunto de lealdades políticas. Cecília não se alinha politicamente ao sistema de governo getulista. Seu poema não se alinha diretamente à crítica (ou louvor) do sistema político vigente pelo Brasil da era Vargas, mesmo porque as questões mais candentes referentes a liberdades individuais já haviam ficado para trás, no período do Estado Novo.

O assunto do poema é a rebelião "precursora da nacionalidade". Seu herói é apresentado como um redentor - da nação, como um herói libertador; dos homens, como um herói que se oferece ao sacrifício para propiciar uma nova etapa na história da humanidade.

Tomadas como exemplo, a Fala Inicial e a Fala aos Inconfidentes Mortos, respectivamente o poema de abertura e de conclusão do Romanceiro, permitem observar um dos leitmotif dos Cenários e das Falas, a memória, bem como sua contraparte negativa, o esquecimento. Esse motivo vem referido como elemento constitutivo da história.

Ao trabalhar a questão do mito nacional, no entanto, o poema retoma a história em função do tema da perplexidade humana diante dos rumos insondáveis do sentido da existência. Constata-se que, no Romanceiro, o trânsito para o mundo do mito não se completa, superando a historicidade e implantando um outro regime simbólico, em que se apagam as contradições presentes no

fragmentum. Santa Maria: UFSM, №1, 2001. 
mundo da realidade, embora, nos versos finais do primeiro Cenário - " 'Adeus! que trabalhar vou para todos!...' // (Esse adeus estremece a minha vida.)" - descortine-se a possibilidade de resolução mítica para o drama da Conjuração. A forma serena que se eleva no ar, prometendo trabalhar para todos ao acenar o adeus, não garante a superação da carência, pois persiste a dúvida sobre a possibilidade de superação, de restauração das promessas originais e, conseqüentemente, da viabilidade política de um futuro regenerado. No poema, essa possibilidade apenas se afigura no plano individual, de crenças e valores do sujeito narrador, anteposta à persistente incerteza acerca da existência de um sentido para a existência do homem.

$\mathrm{Na}$ verdade, é isso que se observa quanto ao plano individual: a falência do projeto de liberdade no nível da realidade dá espaço para a resolução dessa impossibilidade, adiada em esperança no futuro, para o plano mítico. Isto equivale a dizer que, constatada a impossibilidade de concretização do sonho de liberdade no espaço da realidade, num determinado momento da história, a promessa de realização desse sonho transfere-se para 0 plano da transcendência e para um outro momento no futuro, o que geraria a constatação, feita de medo e esperança, do sujeito lírico

No entanto, na Fala aos Inconfidentes Mortos, o que se observa é esse sujeito assumindo a voz coletiva - transformado em nós, abisma-se diante das "torrentes de purgatório", diante das quais não é possível resolver o impasse gerado pelo jogo de cartas do destino humano.

O tom do poema é de ironia e perplexidade diante do semsentido da existência. Desse modo, as respostas convencionais para as questões éticas, ou seja, a determinação do certo e do errado no curso da história, os valores atribuídos às ações, isto é, a ideologia que permeou a sociedade, manifestando-se através dos discursos filosófico, religioso e político, tudo isso cai por terra diante da constatação da arbitrariedade do destino. Tal perplexidade pode ser constatada em todos os níveis, na discussão dos valores da cultura ocidental postos em crise pela Guerra. É assim que, diante do sem-sentido da história e do humano, o filósofo Jean-Paul Sartre lança sua versão do existencialismo, que ancora o humanismo em uma postura de deliberado e consciente compromisso do homem 
com seus semelhantes, como remédio contra a perda de rumos da civilização e barreira interposta à barbárie.

Embora aderindo à necessidade de compromisso e de um sentido para a vida humana, o que fica patente em diversos peças que compõem o Romanceiro, o poema acaba por desacreditar da certeza de uma ordem na realidade. Esse ceticismo, configurando o texto literário, não permite que este, embora trabalhando a partir do mecanismo de transfiguração do histórico em mítico, cumpra-se enquanto mito. Isso significa que, embora a figura central do enredo poético seja elevada à categoria mítica, o poema, enquanto narrativa do percurso desse herói, não consegue resolver as contradições apreendidas enquanto elementos irreconciliáveis na realidade apresentada. Portanto, embora abrigue o mito, o texto literário não se faz, ele mesmo um mito, encerrando em perplexidade. O que, de certa maneira, gera ansiedade no leitor, uma vez que não cumpre as expectativas depositadas no texto. Talvez seja essa experiência de desconforto, exatamente, a medida da grandeza e do poder do poema.

\section{NOTAS}

1 MEIRELES, Cecília. Poesias completas. Rio de Janeiro: Civilização Brasileira, 1979. V. 5. Romanceiro da Inconfidência, p. 3-195.

2 PARAENSE, Sílvia. Cecília Meireles: mito e poesia. Santa Maria: UFSM, CAL, Curso de Mestrado em Letras, 1999.

3 MEIRELES, Cecília. Romanceiro da Inconfidência. Rio de Janeiro: Nova Fronteira, 1989. Como escrevi o "Romanceiro da Inconfidência". p. 11-33.

4 CHAUÍ, Marilena. Brasil - mito fundador e sociedade autoritária. São Paulo: Fundação Perseu Abramo, 2000.

${ }^{5}$ ASSIS, Machado de. Obra completa. Rio de Janeiro: Aguilar, 1973. Vol. 3. Notícia da atual literatura brasileira - instinto de nacionalidade. p. 801; 804.

6 HOBSBAWM, Eric J. Nações e nacionalismo desde 1780: programa, mito e realidade. Rio de Janeiro: Paz e Terra, 1990.

${ }^{7}$ CHAUÍ, Marilena. Op. cit., p. 16.

8 Ibidem, p. 21. 
${ }^{9}$ Ibidem, p. 9.

${ }^{10}$ Ibidem, p. 59-60.

11 lbidem, p. 62.

${ }^{12}$ CHAUÍ, p. 62

${ }^{13}$ DAVALON, Jean. A imagem, uma arte de memória? In: ACHAR, Pierre et al. Papel da memória. Campinas: Pontes, 1999. p. 23.

${ }^{14}$ HALBWACHS, Maurice. La mémoire collective. Paris: PUF, 1950.

${ }^{15}$ DAVALON, J. Op. cit., p. 25.

${ }^{16}$ ACHARD, Pierre. Memória e produção discursiva do sentido. In: ACHARD, Pierre et al. Papel da memória. Campinas: Pontes, 1999. p. 16

17 Ibidem, p. 17.

${ }^{18}$ ORLANDI, Eni Pulcinelli. As formas do silêncio: no movimento dos sentidos. 4. ed. Campinas: Ed. UNICAMP, 1997. p. 13.

${ }^{19}$ RIBEYROLLES, Charles. Brasil pitoresco. Belo Horizonte:

Itatiaia; São Paulo: EDUSP, 1980. Vol. 1.

${ }^{20}$ Transcrição da sentença proferida aos réus de sedição contra 0 poder real, apud RIBEYROLLES, Charles. Op. cit. p. 79-120.

${ }^{21}$ Op. cit., p. 123.

22 Op. cit., p. 122.

${ }^{23}$ ROMERO, Sílvio. História da literatura brasileira. 7 ed. Rio de Janeiro: J. Olympio, 1980. v. 3, p. 851.

${ }^{24}$ SILVA, Joaquim Norberto de Sousa. História da Conjuração Mineira. Rio de Janeiro: Imprensa Oficial, 1948. Apud SERELLE, Márcio. No início da História da Conjuração Mineira: o fato e a ficção na construção da obra de Joquim Norberto de Sousa Silva. Gragoatá. Nitérói, n. 6, p. 177-195, 1. sem. 1999. p191.

${ }^{25}$ Idem, ibidem, p. 188.

${ }^{26}$ RIBEYROLLES, C. Op. cit., p. 122.

${ }^{27}$ SILVA, J. N. de S. e. Op. cit., p. 187.

${ }^{28}$ Ibidem., p. 188

29 LUCAS, Fábio. Luzes e trevas. Minas Gerais no século XVIII. Belo Horizonte: Ed. UFMG, 1998. 